\title{
Management of Lentil Wilt through Host Resistance
}

\author{
Anshul Arya* and K.P.S. Kushwaha \\ Department of Plant Pathology, G.B. Pant University of Agriculture and Technology, \\ Pantnagar, Udham Singh Nagar, 263145, India \\ *Corresponding author
}

Keywords

Screening,

Fusarium

oxysporum f.sp.

lentis, Wilt, Disease rating

Article Info

Accepted:

07 February 2019

Available Online:

10 March 2019

\section{A B S T R A C T}

Lentil (Lens culinaris) is affected by the wilt disease caused by fungal pathogen Fusarium oxysporum f.sp. lentis at seedling stage and at the later stages of growth. The pathogen is soil and seed borne in nature and reported from all lentil growing areas. The present investigation is on the management of the lentil wilt pathogen by exploiting the resistance mechanism of the host. Ninety two germplasms were screened along with the local check (Sehore) under field conditions during the two consecutive years 2016-17 and 2017-18. The reactions of the host against the pathogen were recorded in the wilt sick plot by calculating the per cent of number of infected plants over total plants observed. The germplasms were further categorized into Immune (0 germplasm), Highly Resistant (11 germplasm), Resistant (13 germplams), Moderately Resistant (18 germplams), Susceptible (40 germplams) and Highly Susceptible (10 germplams) depending on the disease reaction. Wilt incidence was varied from 0.33 percent to 96.67 percent during the year 2016-17 and 0.75 percent to 93.56 percent during the year 2017-18. None of the screened germplams was found immune against the disease. Eleven germplasms viz., DL16-5, DL16-7, VL152, IPL339, IPL340, PL237, RL7-3, RVL15-5, IPL227, IPL338 and IPL332 were found highly resistant to the disease under the field conditions. The present investigation suggests that the resistance in the lentil germplasms can be exploited for the management of the seed and soil borne pathogens and is an effective management practice with less use of inputs.

\section{Introduction}

Lentil is an oldest pulse grown globally in different countries like in India, Pakistan, Bangladesh, Italy etc. This pulse is rich source of protein and some other amino acids like lysine and tryptophane. It provides balance nutrition to the humans and its straw is also used as animal feed (Bayaa et al., 1997). Losses in lentil production are governed by several factors including poor seed quality, insect and diseases. Among the diseases, losses caused by wilt disease causing pathogen Fusarium oxysporum f.sp. lentis are severe. Most of the lentil cultivated areas are reported to have this devastating disease in mild to severe form. The pathogen survives in soil as well as in seeds for several years. Pathogen infects the plants in all growth stages from seedling to flowering stage. It was observed that the Warm $\left(25^{\circ} \mathrm{C}\right)$ and dry conditions are the most ideal 
condition for the proliferation of the disease (Bayaa and Erskine 1990). Management of this devastating disease is very necessary to reduce the yield losses of lentil. As management of pathogen in soil with chemicals is difficult due to lack of techniques of infusing chemicals in soil, moreover, chemicals are hazardous for the environment and require more expenses; therefore, management of this pathogen requires some sustainable solution that includes development of resistant varieties of lentil for field use. These resistant germaplasms are eco friendly and feasible, having the potential of resisting the soil borne diseases. Stoilova and Chavdarov (2006) screened thirty two genotypes of lentil against the wilt pathogen and reported the nine germplasms viz., 91-009, 91-011, 93-002, 93040, 95-005, 98-001, 98-013, 2000LEN464 and 2000LEN466, resistant with seedling mortality of 15 percent during all the experiment in the year 2003-2004. Mohammadi et al., (2012) screened 55 lentil germplams and reported three germplams (81S15, FLIP2007-42 L and FLIP2009-18 L) resistant against the wilt disease of lentil. Rafique et al., (2016) reported the five cultivars viz., Markaz-09, Masoor-86, Masoor-2006, Punjab Masoor-00518 and Punjab Masoor-09 resistant to wilt pathogen with 20 to 46.67 percent wilt incidence. Meena et al., (2017) reported lentil germplasms IG 69549 and IG 70238 as highly resistant genotypes based on field and controlled condition screening against wilt pathogen.

\section{Materials and Methods}

The present research was conducted during the two consecutive years 2016-17 and 201718 in the NE Borlaug Crop Research Centre at GBPUAT, Pantnagar, Udham Singh Nagar. Ninety two lentil germplasms along with the susceptible check Sehore were screened against the soil borne pathogen Fusarium oxysporum f.sp. lentis. The germplasms were screened in the wilt sick plot containing the $2.25 \times 10^{3} \mathrm{CFU}$ of the pathogen and germplams were sown in each plot having size of 4.5 meter $^{2}$. The susceptible check (Sehore) was sown between every two rows of germplams as infector. All experiment was conducted in randomized block design maintaining three replications for each entry. Data collection on the basis of symptoms of plant was done at the two stages of plant growth at seedling stage and at flowering stage. The percent disease incidence was also recorded for each germplasm to see the disease impact on the plants. The following formula was used for the calculation of the percent wilt incidence.

$$
\begin{array}{ll}
\text { DI }(\%)= & \begin{array}{l}
\text { No. of infected plants } X \\
100
\end{array} \\
& \begin{array}{l}
\text { Total no. of plants } \\
\text { observed }
\end{array}
\end{array}
$$

The level of resistance existing in the germplasms was determined by using the 1 to 6 disease rating scale (Table 1) given by MULLaRP in technical programme with some modification.

\section{Results and Discussion}

Screening of ninety two lentil germplasms (Table 2) was done against the soil borne pathogen Fusarium oxysporum f.sp. lentis in the wilt sick plot. The uniform distribution of the pathogen inoculums in the wilt sick plot was determined by the hundred percent wilt incidence in the susceptible lentil check (Sehore). The diseased plants showed the yellowing of the leaves started from lower leaves and moved upwards thereby drying of the whole plant. The percent incidence of the wilt disease was obtained as a percent of number of plants infected with the disease out of total number of plants observed. The germplasms were further categorized (Table 
3) into immune, highly resistant, resistant, moderately resistant, susceptible and highly susceptible with the help of 1 to 6 disease rating scale depending on their disease reaction and percent of disease incidence. Out of ninety two germplasms screened none of the germplasms was found free from the diseases infection. Eleven germplams viz., DL16-5, DL16-7, VL152, IPL339, IPL340, PL237, RL7-3, RVL15-5, IPL227, IPL338 and IPL332 were found highly resistant.

The disease incidence was found minimum in germplasm RVL15-5 that was 0.33 percent wilt incidence during the year 2016-17 and 0.77 percent wilt incidence during the year 2017-18. Thirteen germplams viz., VL148, RKL605-3, PL245, VL527, L4729, L4771, IPL535, PL 024, IPL336, IPL536, IPL221, IPL222 and IPL225 were found resistant against the pathogen. The percent of wilt incidence for resistant germplasms was varied from minimum 5.67 percent in germplasm IPL221 to maximum 9.33 percent in VL527 germplasm during the year 2016-17 and 5.26 percent (L4771 and RKL605-3) to 10.00 percent (VL527 and IPL535) during the year 2017-18. Eighteen germplasms (PL 4, L 4147, VL126, LL1370, PL063, RLG250, PL233, PL224, PL221, VL507, JLS-3, L4769, RVL 14-4, IPL 406, LL1373, L4772, IPL537 and
RKL14-114) were found moderately resistant to the disease showing the range of percent wilt incidence from 10.33 percent (VL507) to 19.67 percent (LL1373 and RVL 14-4) during the year 2016-17 and during the year 2017-18 wilt incidence varied from 11.87 percent (IPL 406) to 20.00 percent (PL245).

Forty germplasms (LL 1320, NDL 14-12, L4751， PL406, LL1397, NDL 2016-15, KLS143, LL1383, LL1386, IPL233, IPL 245, VL153, BRL 1, BRL-2, LH 84-8, NDL 201624, KLB112, RVL15-1, RVL15-4, LL1396, LL1467, JLS-1, RKL603-5, VL528, L4728, BPL 16, HUL57, L 4076, JL 3, DPL 62, IPL 316, RKL 14-20, RVL 13-5, RVL 13-7, L 4727, DPL 15, L4773, RKL611-3 and K75,IPL526) were found susceptible showing the percent wilt incidence from 21.00 percent (IPL526 and JLS-1) to 49.33 percent (RKL 14-20) during first year of experiment and 21.00 percent (L 4076) to 49.52 percent (LH 84-8) during the year 2017-18. Ten germplasms viz., IPL230, L 4756, L 4757, KLS218, RL6-1, RL3-5-1, LH1407, IPL81, IPL232 and RL11-07 were found highly susceptible showing percent disease incidence ranging from 54.33 percent (IPL81) to 96.67 percent (L 4757) during the year 2016-17 and 57.26 percent (IPL81) to 91.25 percent (RL61) during the year 2017-18.

Table.1 Disease rating scale for lentil wilt disease caused by Fusarium oxysporum f.sp. lentis

\begin{tabular}{|l|l|l|}
\hline RATING & \% Infected Plants & Disease reactions \\
\hline $\mathbf{1}$ & $0 \%$ infection & Immune (I) \\
\hline $\mathbf{2}$ & 0.1 to $5 \%$ plants & Highly Resistant (HR) \\
\hline $\mathbf{3}$ & 5.1 to $10 \%$ plants wilted & Resistant (R) \\
\hline $\mathbf{4}$ & 10.1 to $20 \%$ plants wilted & Moderately resistant (MR) \\
\hline $\mathbf{5}$ & $20.1-50 \%$ plants wilted & Susceptible (S) \\
\hline $\mathbf{6}$ & Above $50 \%$ & Highly Susceptible (HS) \\
\hline
\end{tabular}


Table.2 Screening of lentil germplams against the wilt pathogen Fusarium oxysporum f.sp. lentis

\begin{tabular}{|c|c|c|c|c|c|c|c|c|c|}
\hline S. No. & Genotype & $\begin{array}{l}\text { Wilt incidence } \\
(\%) 2016\end{array}$ & $\begin{array}{l}\text { Wilt incidence } \\
(\%) 2017\end{array}$ & Reaction & S. No. & Genotype & $\begin{array}{c}\text { Wilt } \\
\text { incidence } \\
\text { (\%) } 2016\end{array}$ & $\begin{array}{l}\text { Wilt incidence } \\
\text { (\%) } 2017\end{array}$ & Reaction \\
\hline 1. & PL 4 & 19.33 & 18.42 & MR & 47. & PL221 & 17.22 & 18.45 & MR \\
\hline 2. & L 4147 & 17.00 & 15.71 & MR & 48. & LH 84-8 & 47.67 & 49.52 & $\mathrm{~S}$ \\
\hline 3. & VL126 & 16.33 & 17.26 & MR & 49. & VL507 & 10.33 & 12.00 & MR \\
\hline 4. & VL148 & 7.67 & 5.26 & $\mathrm{R}$ & 50. & NDL 2016-24 & 25.33 & 26.34 & $\mathrm{~S}$ \\
\hline 5. & LL 1320 & 25.82 & 27.23 & S & 51. & RL6-1 & 89.00 & 91.25 & HS \\
\hline 6. & NDL 14-12 & 43.00 & 41.26 & $\mathrm{~S}$ & 52. & RL3-5-1 & 79.33 & 81.25 & HS \\
\hline 7. & L4751 & 35.67 & 38.21 & $\mathrm{~S}$ & 53. & LH1407 & 71.00 & 73.25 & HS \\
\hline 8. & LL1370 & 16.67 & 15.53 & MR & 54. & KLB112 & 33.00 & 29.56 & $S$ \\
\hline 9. & PL406 & 27.67 & 29.38 & $\mathrm{~S}$ & 55. & RVL15-1 & 25.33 & 27.13 & $\mathrm{~S}$ \\
\hline 10. & PL063 & 18.67 & 16.52 & MR & 56. & RVL15-4 & 26.33 & 25.66 & $\mathrm{~S}$ \\
\hline 11. & LL1397 & 47.33 & 45.32 & S & 57. & LL1396 & 45.67 & 47.21 & $S$ \\
\hline 12. & IPL230 & 81.00 & 76.32 & HS & 58. & LL1467 & 27.67 & 30.04 & $\mathrm{~S}$ \\
\hline 13. & NDL 2016-15 & 40.67 & 38.26 & S & 59. & JLS-1 & 21.00 & 23.52 & $\mathrm{~S}$ \\
\hline 14. & KLS143 & 23.33 & 21.22 & $\mathrm{~S}$ & 60. & JLS-3 & 19.33 & 18.36 & MR \\
\hline 15. & LL1383 & 46.67 & 48.23 & S & 61. & IPL339 & 4.00 & 3.01 & HR \\
\hline 16. & LL1386 & 37.00 & 37.82 & $\mathrm{~S}$ & 62. & IPL340 & 2.67 & 4.25 & HR \\
\hline 17. & IPL233 & 33.00 & 31.26 & $\mathrm{~S}$ & 63. & RKL603-5 & 32.00 & 29.42 & $\mathrm{~S}$ \\
\hline 18. & IPL 245 & 39.33 & 41.23 & S & 64. & RKL605-3 & 7.00 & 5.23 & $\mathrm{R}$ \\
\hline 19. & RLG250 & 16.00 & 17.21 & MR & 65. & PL245 & 19.33 & 20.00 & $\mathrm{R}$ \\
\hline 20. & PL233 & 11.33 & 13.55 & MR & 66. & PL237 & 5.00 & 4.61 & HR \\
\hline 21. & PL224 & 13.00 & 14.75 & MR & 67. & VL527 & 9.33 & 10.00 & $\mathrm{R}$ \\
\hline 22. & DL16-5 & 2.33 & 4.00 & HR & 68. & VL528 & 34.33 & 36.47 & $\mathrm{~S}$ \\
\hline
\end{tabular}




\begin{tabular}{|c|c|c|c|c|c|c|c|c|c|}
\hline 23. & DL16-7 & 2.67 & 3.12 & HR & 69. & L4728 & 45.67 & 47.25 & $\mathrm{~S}$ \\
\hline 24. & VL152 & 1.33 & 2.01 & HR & 70. & L4729 & 8.00 & 9.23 & $\mathrm{R}$ \\
\hline 25. & VL153 & 25.00 & 27.33 & $\mathrm{~S}$ & 71. & L4769 & 15.00 & 13.58 & MR \\
\hline 26. & BRL 1 & 42.00 & 43.23 & $\mathrm{~S}$ & 72. & L477 1 & 7.00 & 5.26 & $\mathrm{R}$ \\
\hline 27. & BRL-2 & 36.00 & 39.22 & $\mathrm{~S}$ & 73. & RL7-3 & 4.67 & 3.42 & HR \\
\hline 28. & L 4756 & 58.67 & 63.23 & HS & 74. & IPL535 & 8.00 & 10.00 & $\mathrm{R}$ \\
\hline 29. & L 4757 & 96.67 & 93.56 & HS & 75. & IPL536 & 8.00 & 9.44 & $\mathrm{R}$ \\
\hline 30. & BPL 16 & 48.00 & 45.12 & $S$ & 76. & RVL15-5 & 0.33 & 0.75 & HR \\
\hline 31. & KLS218 & 69.67 & 65.23 & HS & 77. & L4772 & 15.67 & 17.25 & MR \\
\hline 32. & HUL57 & 46.67 & 43.32 & $\mathrm{~S}$ & 78. & L4773 & 45.67 & 47.25 & $\mathrm{~S}$ \\
\hline 33. & L 4076 & 22.67 & 21.00 & S & 79. & IPL537 & 14.00 & 13.25 & MR \\
\hline 34. & JL 3 & 42.00 & 40.85 & $\mathrm{~S}$ & 80. & RKL14-114 & 14.67 & 14.00 & MR \\
\hline 35. & DPL 62 & 22.67 & 21.36 & S & 81. & RKL611-3 & 28.67 & 31.25 & $\mathrm{~S}$ \\
\hline 36. & IPL 316 & 42.00 & 40.26 & $\mathrm{~S}$ & 82. & K75 & 32.00 & 34.15 & $\mathrm{~S}$ \\
\hline 37. & RKL 14-20 & 49.33 & 47.25 & S & 83. & IPL81 & 54.33 & 57.26 & HS \\
\hline 38. & RVL 13-5 & 32.00 & 29.55 & $\mathrm{~S}$ & 84. & IPL221 & 5.67 & 7.45 & $\mathrm{R}$ \\
\hline 39. & RVL 13-7 & 39.67 & 41.13 & $\mathrm{~S}$ & 85. & IPL222 & 10.00 & 9.45 & $\mathrm{R}$ \\
\hline 40. & L 4727 & 22.67 & 24.32 & $S$ & 86. & IPL225 & 6.67 & 7.45 & $\mathrm{R}$ \\
\hline 41. & RVL 14-4 & 19.67 & 20.00 & MR & 87. & IPL227 & 2.67 & 3.00 & HR \\
\hline 42. & DPL 15 & 24.33 & 21.58 & $\mathrm{~S}$ & 88. & IPL338 & 4.00 & 4.75 & HR \\
\hline 43. & IPL 406 & 13.67 & 11.87 & MR & 89. & IPL332 & 3.67 & 4.00 & HR \\
\hline 44. & PL 024 & 8.00 & 9.11 & $\mathrm{R}$ & 90. & IPL232 & 62.00 & 64.25 & HS \\
\hline 45. & LL1373 & 19.67 & 18.23 & MR & 91. & IPL526 & 21.00 & 23.33 & $\mathrm{~S}$ \\
\hline 46. & IPL336 & 6.67 & 7.84 & $\mathrm{R}$ & 92. & RL11-07 & 76.33 & 74.12 & HS \\
\hline
\end{tabular}


Table.3 Categorization of the lentil germplasms on the basis of disease reaction against Fusarium oxysporum f.sp. lentis

\begin{tabular}{|c|c|c|}
\hline S.No. & $\begin{array}{l}\text { Disease } \\
\text { Reactions }\end{array}$ & Germplasms \\
\hline 1. & Immune & Nil \\
\hline 2. & $\begin{array}{l}\text { Highly } \\
\text { Resistant (11) }\end{array}$ & $\begin{array}{l}\text { DL16-5, DL16-7, VL152, IPL339, IPL340, PL237, RL7-3, } \\
\text { RVL15-5, IPL227, IPL338, IPL332 }\end{array}$ \\
\hline 3. & Resistant(13) & $\begin{array}{l}\text { VL148, RKL605-3, PL245, VL527, L4729, L4771, IPL535, PL } \\
\text { 024, IPL336 } \\
\text { IPL536, IPL221, IPL222, IPL225 }\end{array}$ \\
\hline 4. & $\begin{array}{l}\text { Moderately } \\
\text { resistant (18) }\end{array}$ & $\begin{array}{l}\text { PL 4, L 4147, VL126, LL1370, PL063, RLG250, PL233, PL224, } \\
\text { PL221, VL507, JLS-3, L4769, RVL 14-4, IPL 406, LL1373, } \\
\text { L4772, IPL537, RKL14-114 }\end{array}$ \\
\hline 5. & $\begin{array}{l}\text { Susceptible } \\
(40)\end{array}$ & $\begin{array}{l}\text { LL 1320, NDL 14-12, L4751, PL406, LL1397, NDL 2016-15, } \\
\text { KLS143, LL1383, LL1386, IPL233, IPL 245, VL153, BRL 1, } \\
\text { BRL-2, LH 84-8, NDL 2016-24, KLB112, RVL15-1, RVL15-4, } \\
\text { LL1396, LL1467, JLS-1, RKL603-5, VL528, L4728, BPL 16, } \\
\text { HUL57, L 4076, JL 3, DPL 62, IPL 316, RKL 14-20, RVL 13-5, } \\
\text { RVL 13-7, L 4727, DPL 15, L4773, RKL611-3, K75,IPL526 }\end{array}$ \\
\hline 6. & $\begin{array}{l}\text { Highly } \\
\text { Susceptible(10) }\end{array}$ & $\begin{array}{l}\text { IPL230, L 4756, RL6-1, RL3-5-1, LH1407, L 4757, KLS218, } \\
\text { IPL81, IPL232 } \\
\text { RL11-07 }\end{array}$ \\
\hline
\end{tabular}

The results obtained are similar to the results obtained by some other researchers those also found the resistant cultivars through screening of germplasms using sick plot technique. Soomro et al., (2018) revealed that NIAMasoor-05, lentil-25 was comparatively resistant against infection of wilt pathogen followed by Masoor-93 and Markaz-09. Koleva et al., (2018) reported six lentil accessions (two cultivars and four lines) as moderately resistant phenotype after inoculation with Fusarium oxysporum f.sp. lentis.
The present study concluded that the one germplasm RVL15-5 was found highly resistant to the disease as it showed the percent wilt incidence less than 1 percent in both years of experiment. The germplasm like VL152 (1.33\%), DL16-5 (2.33\%), IPL340 (2.67\%), IPL227 (2.67\%), DL16-7 (2.67\%), IPL332 (3.67\%), IPL338 (4.00\%), IPL339 (4.00\%), RL7-3 (4.67\%) and PL237 (5.00\%) etc. were also found highly resistant for the disease. The present study revealed that the inherent ability of the host plant to resist the pathogen allow the host to survive under the 
abundance of the pathogen inoculums without economic damage to the host and does not require any other inputs for disease escape. Use of the resistant germplasms is eco friendly approach for the disease management as well as economical for the farmers and could be a part of Integrated Disease Management practices.

\section{References}

Bayaa B, Erskine W and Singh M. 1997. Screening lentil for resistance to Fusarium wilt: methodology and source of resistance. Euphytica. 98:6974.

Bayaa, B. and Erskine, W. 1990. A screening technique for resistance to vascular wilt in lentil. Arab Journal of Plant Protection. 8: 30-33.

Koleva M, Stanoeva Y, Kiryakov I, Ivanova A, Chamurlyiski P. 2018. Evaluation of lentil cultivars and lines for resistance to Fusarium oxysporum f.sp. lentis. Agricultural Science and Technology. 10(1): 25-28.

Meena JK, Singh A, Dikshit HK, Mishra GP, Aski M, Srinivasa N, Gupta S, Singh D and Tripathi A. 2017. Screening of Lentil (Lens culinaris Medikus sub sp. culinaris) Germplasm against Fusarium Wilt (Fusarium oxysporum f. sp. lentis). International Journal of Current Microbiology and Applied Science. 6(11): 2533-2541.

Mohammadi N, Puralibaba H, Goltapeh EM, Ahari AB and Sardrood BP. 2012. Advanced lentil lines screened for resistance to Fusarium oxysporum $\mathrm{f}$. sp. lentis under greenhouse and field conditions. Phytoparasitica. 40:69-76.

Rafique K, Rauf CA, Naz F and Shabbir G.2016. Management of Vascular Wilt of Lentil through Host Plant Resistance, Biological Control Agents and Chemicals. Pakistan Journal of Botany 48(5): 2085-2092.

Soomro MP, Wagan KH, Dhiloo KH, Soomro SP, Soomro MH, Hassan S, Yaseen M, Hajano J, Mastoi SM and Mastoi PM. 2018. Response of lentil varieties against Fusarium wilt. Journal of Entomology and Zoology Studies. 6(1): 858-862.

Stoilova T and Chavdarov P. 2006. Evaluation of Lentil Germplasm For Disease Resistance To Fusarium Wilt (Fusarium oxysporum f.sp. lentis). Journal of Central European Agriculture. 7(1): 121-126.

\section{How to cite this article:}

Anshul Arya and Kushwaha, KPS. 2019. Management of Lentil Wilt through Host Resistance. Int.J.Curr.Microbiol.App.Sci. 8(03): 438-444. doi: https://doi.org/10.20546/ijcmas.2019.803.055 